\title{
Special issue "Towards forecasting phreatic eruptions: examples from Hakone volcano and some global equivalents"
}

\author{
Kazutaka Mannen ${ }^{*}$ (E), Diana Roman², Graham Leonard ${ }^{3}$, Stephanie Prejean ${ }^{4}$ and Mitsuhiro Nakagawa ${ }^{5}$
}

\begin{abstract}
Introduction
Volcanic eruptions are among the most spectacular natural phenomena on Earth and incandescent magmatic eruptions in particular have fascinated humans throughout history. Among the wide variety of volcanic eruptions, phreatic eruptions, which are non-magmatic and typically small in size, have received far less attention from researchers, and the number of research papers on phreatic eruptions has been far lower than those on magmatic eruptions. This does not mean phreatic eruption is a rare phenomenon-in fact, phreatic eruptions are common and may in fact outnumber magmatic eruptions.

A recent extensive review counted 116 phreatic eruptions of 36 volcanoes during the period from 1900 to 2015 (approximately one per year on average) in Japan, which has very detailed records of volcanic eruptions (Oikawa et al. 2018). However, few of these eruptions had interested volcanologists probably because limited ash dispersal and geophysical observations did not allow detailed analysis. The tragic eruption at Mt. Ontake in 2014, which killed 63 hikers, and the eruption (from an unexpected eruption center) at Mt. Kusatsu-Shirane in 2018, which killed a self-defense force personnel at drill seemed to change the mindsets of the volcanologists in Japan. Although detailed analysis of the 2018 eruption of Mt. Kusatsu-Shirane (Ogawa et al. 2018) is still ongoing, a special issue for the 2014 eruption of Mt. Ontake was organized in this journal, and compiled observations and models of preparatory process of this unexpected
\end{abstract}

\footnotetext{
*Correspondence: mannen@onken.odawara.kanagawa.jp

${ }^{1}$ Hot Springs Research Institute of Kanagawa Prefecture, 586 Iriuda,

Odawara, Kanagawa 250-0031, Japan

Full list of author information is available at the end of the article
}

eruption, which resulted largest number of victims after World War II (Yamaoka et al. 2016).

The phreatic eruption of Hakone volcano, Japan, in 2015 was accompanied by a variety of intense precursors and mitigation measures, which included establishment of a no-entry zone by the municipal office and raising of the Volcano Alert Level by Japan Meteorological Agency. In contrast to Kusatsu-Shirane and Ontake, Hakone volcano is an 'urbanized' volcano, which enables researchers to access this potential eruption center frequently and to deploy geophysical instruments connected to electric and communication grids. The 2015 eruption of Hakone is thus an unprecedentedly well-monitored phreatic eruption. This special issue compiles a variety of papers that propose models of the hydro-magmatic system of Hakone and some global equivalents based on various observations.

Here, we review the contributions in the special issue with related papers published in other journals.

\section{Content of the special issue Modeling of phreatic eruptions}

A phreatic eruption is an eruption without any eruption of juvenile magma. However, recent studies imply that subsurface injection of magma or magmatic fluid can trigger volcanic unrest and subsequent phreatic eruptions (e.g., Yamaoka et al. 2016). In this special issue, two contributions modeled the sequence from an event of magma or magmatic fluid injection at depth to a phreatic eruption through various precursory phenomena.

Stix and de Moor (2018) compiled recent studies of phreatic eruptions and proposed two endmembers for phreatic systems. Type 1 systems are characterized by a sealed hydrothermal system. Injection of magmatic fluids 
causes pressurization of the hydrothermal system and eventual rupture of the seal, generating ballistics, and fine ash. For a Type 2 system, input of magmatic fluids into a near-surface hydrothermal system vaporizes liquid water, promoting eruptions which emit wet ash, lahars, and/or ballistics. Since injection of magmatic fluids and rupture of hydrothermal seals are potentially seismogenic processes, they suggest that monitoring of broadband seismicity and gas ratios is useful approaches to forecasting phreatic eruptions.

Mannen et al. (2018) compiled geological and geophysical observations during the 2015 phreatic eruption of Hakone Volcano and its precursory unrest, and proposed that magma replenishment of a $10-\mathrm{km}$-deep magma chamber and subsequent pressurization of the hydrothermal system caused the volcanic unrest. The seismic activity reached its climax more than a month before the eruption; however, a pressure increase in the hydrothermal system continued even after the eruption. Since the eruption was caused by sudden formation of an open crack filled with hydrothermal fluid, short-term forecasting of a phreatic eruption was challenging.

\section{Cap rock and sealing zone}

A phreatic eruption is a phenomenon that releases hydrothermal fluids confined beneath a volcano. Such a confinement is seemingly attained by geological structures such as cap rock or sealing zone. To understand phreatic eruptions, the characterization of the properties of these structures, including their location, depth, and function in the context of the magma-hydrothermal system of the volcano is necessary. In the special issue, three contributions focused on investigations of cap rock and sealing zones (Ueda et al. 2018; Yoshimura et al. 2018; Ohba et al. 2019).

Yoshimura et al. (2018) conducted an audio-frequency magnetotelluric (AMT) survey at 39 sites, covering the whole of Hakone caldera before the eruption, and established a three-dimensional model of the resistivity structure of the volcano. The survey found a significant $(<10$ $\Omega \mathrm{m}$ ) bell-shaped conductor beneath the center of the volcano. The apex of the bell-shaped conductor locates near the center of the volcano beneath the 2015 eruption vent. Beneath the conductor is a seismic zone which had been active during the previous periods of volcanic unrest. Since the previous study proposed that the seismic activity of the volcano had been triggered by pressure rise or fluid migration (Yukutake et al. 2011), the bell-shaped conductor is interpreted as the cap rock that confines a hydrothermal system.

Ohba et al. (2019) compiled long-term gas observations and developed a hydrothermal model of Hakone volcano in which a sealing zone just above the magma chamber controls volcanic unrest. In the model, the sealing zone has some permeability during background periods; however, a few months before the onset of volcanic unrest, changes in permeability of the zone began to restrict gas migration from the magma chamber to the hydrothermal system. The restriction allowed infiltration of atmospheric gases such as Ar and $\mathrm{N}_{2}$ into the hydrothermal system. The increase in seismicity during volcanic unrest was triggered by breakage of the sealing zone, resulting in a transfer of confined pressure beneath the sealing zone into the hydrothermal system as indicated by the observed increase of $\mathrm{CO}_{2} / \mathrm{H}_{2} \mathrm{O}$ ratios.

Ueda et al. (2018) compiled geophysical and geological observations of a volcanic island named Ioto, which is also known as Iwo-jima for the fierce battle between Japan and the United States during World War II. At this volcano, phreatic eruptions with seismic precursors occur during intermittent uplift. This type of phreatic eruption is interpreted as a result of boiling of the hydrothermal reservoirs triggered by deep magma intrusion. The hydrothermal fluid reaches the surface through fault systems developed near the margin of hydrothermal reservoirs and these types of eruptions form craters along the fault zone. In contrast, phreatic eruptions at Ioto that occur without any precursors are small and similar to geyser eruptions.

\section{Geological study}

Phreatic eruptions are the smallest type of volcanic eruption in terms of erupted volume. Since the volume of erupted material is so small, the resulting deposits are washed out swiftly and it is very difficult to reconstruct an ancient phreatic eruption from study of the geologic record. Thus, detailed description and analysis of an eruption deposit soon after a phreatic eruption is critical to understand the eruption mechanism and to establish mitigation measures. For example, a detailed analysis of erupted material of the 2015 Hakone eruption implied the very shallow source of the explosion (Yaguchi et al. 2019). This special issue has four contributions documenting geological investigations immediately following phreatic eruptions (Geshi and Itoh 2018; Kataoka et al. 2018, 2019; Kilgour et al. 2019). In addition, Ikehata et al. (2019) is a rare but valuable contribution discussing the formation mechanism of sulfur deposits, which is a common but generally understudied volcanic deposit.

Kilgour et al. (2019) undertook a comprehensive surface investigation just after an eruption at White Island, New Zealand. They deployed drones to swiftly map the distribution of ballistic blocks. Based on the observed distribution and a simulation code named Ballista (Tsunematsu et al. 2014), they estimated the initial velocity of ballistics as $50-65 \mathrm{~m} / \mathrm{s}$, which is very low 
when compared to global equivalents. In addition, they revealed that topography around the eruption center significantly affects the distributions of surge deposits and ballistics.

Geshi and Itoh (2018) described a pyroclastic density current (PDC) formed during the 2015 phreatomagmatic eruption at Kuchinoerabu volcano in detail. The PDC was generated by partial collapse of an eruption column, which rose up to $9 \mathrm{~km}$ above sea level, and flowed along a valley to reach the coast of the island approximately $2.4 \mathrm{~km}$ away from the source crater. The estimated temperature of the PDC at Kuchinoerabu during this phreatic eruption was between 100 and 240$270{ }^{\circ} \mathrm{C}$, which is less than that of typical magmatic PDC $\left(>300{ }^{\circ} \mathrm{C}\right)$. However, the PDC of Kuchinoerabu was still energetic and trees near the vent area were broken.

Kataoka et al. (2018) emphasizes that characteristics of post-eruptive lahars that occur after a single eruptive event can have significant differences depending on the trigger. After the 2014 Ontake eruption, two types of lahars occurred within 7 months: a rain-triggered type and a rain-on-snow type. The rain-triggered lahar, which took place during a rain storm 8 days after the eruption, deposited muddy and high-clay content sediment. In contrast, a rain-on-snow-type lahar, which is caused by heavy rain and snow melting, formed a fines-depleted sandy and gravelly deposit. Such a significant difference in post-eruptive lahars should be considered when implementing simulations and formulating mitigation plans.

Kataoka et al. (2019) monitored sediment transport by rivers running from the eruption center of the 2014 Ontake eruption and revealed that the influence of volcanic disturbance on the catchment continued for at least 10 months after the eruption and an additional 9 months until the end of the snowmelt season in 2016.

\section{Simulation and analogue experiments}

Simulations can examine the influence of a simple key mechanism on the subsequent complex behavior of the volcanic system. In this special issue, two contributions document simple-but-insightful simulation experiments (Noguchi et al. 2018; Tanaka et al. 2018).

Noguchi et al. (2018) focused on rootless eruptions caused by lava flows entering inland water or water-rich sediment. This type of eruption forms craters with significant explosion energy distal from the actual source vent; however, forecasting of these occurrences has remained difficult. Their unique analogue experiment using cooking ingredients such as syrup and baking powder shows a non-linear relationship between reaction efficiency and baking soda/poured heated syrup (=water/lava) proportion which may stem from a Rayleigh-Taylor instability occurring between lava and substrate water or sediment.
Tanaka et al. (2018) implemented a numerical simulation of a conduit system, through which hydrothermal fluid reaches the surface, and monitored crater temperature and pressure distribution of the edifice interior after changing the permeability of the conduit. The simulation showed how crater temperature can decrease before a phreatic eruption. They also showed the potential of their simulation to understand mechanisms of phreatic eruption with observations of crater temperature and ground deformation.

\section{InSAR}

InSAR (Interferometric Synthetic-Aperture Radar) presently plays a key role in volcano monitoring. During the 2015 Hakone eruption and unrest, InSAR data were critically important for planning mitigation measures (Mannen et al. 2018) and has to date resulted in three prominent literature contributions related to InSAR, two in this special issue (Doke et al. 2018; Kuraoka et al. 2018) and one in another journal (Kobayashi et al. 2018).

Doke et al. (2018) detected the open crack that was formed by the 2015 eruption by analysis of ground deformation observed by satellite InSAR. The eruption center was formed at the northern end of the open crack. Since old craters align on the ground surface just above the open crack, the 2015 eruption was interpreted as a reactivation of a pre-existing crack that was formed by earlier eruptions. The detailed analysis of Doke et al. (2018) detected a sill-like deflation source beneath the crack, which is considered the source of hydrothermal fluid that formed the open crack. The pre-eruptive pressurization of the hydrothermal system of the volcano was also detected as local uplift by the InSAR analysis.

Kuraoka et al. (2018) installed a ground-based InSAR (GBInSAR) 4 days before the 2015 eruption to monitor the local uplift observed by satellite InSAR. Fortunately, the 2015 eruption took place within the monitoring area and ground deformation associated with the eruption was recorded with high sampling rate $(<10 \mathrm{~min})$. The 2015 eruption initiated crack intrusion at 7:32 and emission of highly pressurized fluid as inferred from infrasonic analysis (Yukutake et al. 2018). Curiously, the GBInSAR interferometry failed at the onset time and during the subsequent $46 \mathrm{~min}$; however, ground deformation after the crack formation was still monitored in detail, and this successful observation implies significant potential of this technology for volcano monitoring and alerting.

Kobayashi et al. (2018) undertook a detailed analysis of InSAR and GNSS data and proposed two inflation sources: a deep spherical source at $4.5 \mathrm{~km}$ below sea level (BSL), interpreted as a potential magma chamber, and a shallow source (at approximately $150 \mathrm{~m}$ below 
the surface) which caused very local surface deformation detected by InSAR. Similar deformation sources are also deduced in papers in the special issue; however, the emphasis of Kobayashi et al. (2018) is on synchronization of the deformation rate changes of the two sources, which implies smooth fluid migration from deep to shallow. Kobayashi et al. (2018) also showed that subtle inflation of the two sources initiated in late 2014, long before the acceleration of inflation beginning in May 2015.

\section{Signals emitted by phreatic eruption-location and source analysis}

Phreatic eruptions emit various waveforms that are triggered by migration of hydrothermal fluid; thus, the location and depth of these signals are of primary importance for understanding the mechanism of the eruption. In addition, the interpretation and timing of seismic and acoustic events in the sequence of the eruption can help constrain eruption process. This special issue collected intriguing examples from White Island, Kawah Ijen, and Hakone (Yukutake et al. 2017, 2018; Caudron et al. 2018; Harada et al. 2018; Jolly et al. 2018; Walsh et al. 2019).

Walsh et al. (2019) located eruptive pulses emitted during a phreatic eruption that occurred at White Island on 27 April 2018 by a joint analysis combining acoustic and seismic data. The locations of the eruption vent were inferred using an amplitude source location method, and the depth of eruption pulses was inferred from volcanic acoustic-seismic ratios. After error analysis, the eruption sources are shown to conceivably come from a single vent with the eruption pulses gradually increasing in strength with time.

Jolly et al. (2018) focused on very-long-period (VLP) seismic events during the 2018 phreatic eruption of White Island volcano. The VLP was located through analysis of waveform semblance and the volumetric source of the largest VLP event was obtained by seismic waveform inversion. The pre-eruptive VLP seems to be linked to advection of gas from the VLP source location at the magmatic carapace, approximately 800 to $1000 \mathrm{~m}$ depth.

Caudron et al. (2018) carefully processed broadband seismic signals of VLP events from two similar volcanoes: Kawah Ijen (Indonesia) and White Island (New Zealand). The phreatic eruptions of both volcanoes initiated with a VLP seismic event at shallow levels beneath the crater region. The VLP events may be triggered by excitation of gas trapped behind a ductile magma carapace, followed by response of shallow hydrothermal system. Since signals emitted by these processes are long period and can be recorded only by broadband seismometers, the authors emphasize the importance of deploying broadband seismometers near active volcanic centers.
Yukutake et al. (2018) extracted infrasound signals emitted from the eruption center of the 2015 Hakone eruption from noisy (wind) data using the record of a co-located seismometer (Ichihara et al. 2012). Due to the poor visibility at the time of eruption, the exact timing of the eruption onset remains obscure and conventional geological observations only detected a lahar, which initiated in the late morning as the initial emission (Mannen et al. 2018). However, the extracted infrasound signal indicates an emission of highly pressurized fluid at 07:32 A.M. (JST), which is the timing of formation of the initial open crack that triggered the eruption (Honda et al. 2018).

Honda et al. (2018) observed a rapid tilt change at Hakone Volcano, which started $10 \mathrm{~s}$ before 07:33 A.M. (JST) and lasted for approximately $2 \mathrm{~min}$. The tilt change, which occurred long before the initiation of ash dispersal at approximately 12:30 P.M. (JST), was observed not only by tiltmeters but also by broadband seismometers, which were temporarily deployed around the eruption center. The tilt change was considered to be caused by a crack intrusion, and analysis of the tilt record revealed the parameters of the crack, such as its location, depth, and opening. Since the opening of the crack is small $(<10 \mathrm{~cm})$, it is highly unlikely that magma (as opposed to hydrothermal fluids) filled the crack.

Harada et al. (2018) monitored the rate of inflation of Hakone volcano using GNSS, beginning when precursory unrest started approximately 3 months before the 2015 eruption, and modeled the inflation sources. The deep source at $6.5 \mathrm{~km} \mathrm{BSL}$, which is interpreted as a magma chamber, first started inflating at the end of March, then the shallow open crack at approximately $800 \mathrm{~m}$ ASL started inflating in mid-May. Interestingly, both sources continued inflating even after the eruption on Jun. 29 and until early August. This observation implies that the phreatic eruption did not relieve the pressure in the hydrothermal system significantly.

Yukutake et al. (2017) estimated the source location of the continuous volcanic tremor observed during the 2015 Hakone eruption using a cross-correlation analysis of waveform envelopes. The source of the tremor is determined to be near the vent of the eruption. The amplitude of the tremor increased coincident with the occurrence of impulsive infrasonic waves and the largest amplitude was observed at the end of the eruption. The analysis suggests that both seismic and infrasonic waves were generated when a gas slug bursts at the surface of the vent. 


\section{Conclusion}

This special issue is a collection of the latest studies on phreatic eruptions from various aspects. We expect that this timely special issue will help further advances in understanding of phreatic eruptions, towards the goal of forecasting their occurrence.

\section{Abbreviations}

GBInSAR: Ground-Based Interferometric Synthetic-Aperture Radar; GNSS: Global Navigation Satellite System; InSAR: Interferometric Synthetic-Aperture Radar; JST: Japan Standard Time; PDC: pyroclastic density current; VLP: very long period.

\section{Acknowledgements}

Not applicable.

\section{Authors' contributions}

All authors read and approved the final manuscript.

\section{Funding}

Not applicable.

\section{Availability of data and materials \\ Not applicable.}

\section{Competing interests}

The authors declare that they have no competing interests.

\section{Author details}

${ }^{1}$ Hot Springs Research Institute of Kanagawa Prefecture, 586 Iriuda, Odawara, Kanagawa 250-0031, Japan. ${ }^{2}$ Department of Terrestrial Magnetism, Carnegie Institution for Science, 5241 Broad Branch Road, NW, Washington, DC 20015-1305, USA. ${ }^{3}$ GNS Science, 1 Fairway Drive, Lower Hutt, New Zealand. ${ }^{4}$ USAID-USGS Volcano Disaster Assistance Program, Volcano Science Center, 4230 University Avenue, Anchorage, AK 99508, USA. ${ }^{5}$ Graduate School of Science, Hokkaido University, Kita 8 Nishi 5, Kita, Sapporo, Hokkaido 060-0808, Japan

Received: 31 July 2019 Accepted: 3 August 2019

Published online: 29 August 2019

\section{References}

Caudron C, Taisne B, Neuberg J et al (2018) Anatomy of phreatic eruptions. Earth Planets Space 70:168. https://doi.org/10.1186/s40623-018-0938-x

Doke R, Harada M, Mannen K et al (2018) InSAR analysis for detecting the route of hydrothermal fluid to the surface during the 2015 phreatic eruption of Hakone Volcano, Japan. Earth Planets Space 70:63. https://doi. org/10.1186/s40623-018-0834-4

Geshi N, Itoh J (2018) Pyroclastic density currents associated with the 2015 phreatomagmatic eruption of the Kuchinoerabujima volcano. Earth Planets Space 70:119. https://doi.org/10.1186/s40623-018-0881-x

Harada M, Doke R, Mannen K et al (2018) Temporal changes in inflation sources during the 2015 unrest and eruption of Hakone volcano, Japan. Earth Planets Space 70:152. https://doi.org/10.1186/s40623-018-0923-4

Honda R, Yukutake Y, Morita Y et al (2018) Precursory tilt changes associated with a phreatic eruption of the Hakone volcano and the corresponding source model. Earth Planets Space 70:117. https://doi.org/10.1186/s4062 3-018-0887-4

Ichihara M, Takeo M, Yokoo A et al (2012) Monitoring volcanic activity using correlation patterns between infrasound and ground motion. Geophys Res Lett 39:L04304. https://doi.org/10.1029/2011GL050542

Ikehata K, Date M, Ishibashi J et al (2019) Solid sulfur spherules near fumaroles of Hakone volcano, Japan. Int J Earth Sci 108(1):347-356. https://doi. org/10.1007/s00531-018-1657-z
Jolly A, Lokmer I, Christenson B, Thun J (2018) Relating gas ascent to eruption triggering for the April 27, 2016, White Island (Whakaari), New Zealand eruption sequence. Earth Planets Space 70:177. https://doi.org/10.1186/ s40623-018-0948-8

Kataoka KS, Matsumoto T, Saito T et al (2018) Lahar characteristics as a function of triggering mechanism at a seasonally snow-clad volcano: contrasting lahars following the 2014 phreatic eruption of Ontake Volcano, Japan. Earth Planets Space 70:113. https://doi.org/10.1186/s40623-018-0873-x

Kataoka KS, Matsumoto T, Saito T et al (2019) Suspended sediment transport diversity in river catchments following the 2014 phreatic eruption at Ontake Volcano, Japan. Earth Planets Space 71:15. https://doi. org/10.1186/s40623-019-0994-x

Kilgour G, Gates S, Kennedy B et al (2019) Phreatic eruption dynamics derived from deposit analysis: a case study from a small, phreatic eruption from Whakāri/White Island, New Zealand. Earth Planets Space 71:36. https:// doi.org/10.1186/s40623-019-1008-8

Kobayashi T, Morishita Y, Munekane H (2018) First detection of precursory ground inflation of a small phreatic eruption by InSAR. Earth Planet Sci Lett 491:244-254. https://doi.org/10.1016/j.epsl.2018.03.041

Kuraoka S, Nakashima Y, Doke R, Mannen K (2018) Monitoring ground deformation of eruption center by ground-based interferometric synthetic aperture radar (GB-InSAR): a case study during the 2015 phreatic eruption of Hakone volcano. Earth Planets Space 70:181. https://doi.org/10.1186/ s40623-018-0951-0

Mannen K, Yukutake Y, Kikugawa G et al (2018) Chronology of the 2015 eruption of Hakone volcano, Japan-geological background, mechanism of volcanic unrest and disaster mitigation measures during the crisis. Earth Planets Space 70:68. https://doi.org/10.1186/s40623-018-0844-2

Noguchi R, Hamada A, Suzuki Al, Kurita K (2018) Experimental approach to rootless eruptions using kitchen materials. Earth Planets Space 70:208. https://doi.org/10.1186/s40623-018-0974-6

Ogawa Y, et al. (2018) Comprehensive survey of 2018 Kusatsu-Shirane eruption. In: Proc. Symp. on the natural disaster sciences. vol. 55, pp 25-30 (in Japanese)

Ohba T, Yaguchi M, Nishino K et al (2019) Time variations in the chemical and isotopic composition of fumarolic gases at Hakone volcano, Honshu Island, Japan, over the earthquake swarm and eruption in 2015, interpreted by magma sealing model. Earth Planets Space 71:48. https://doi. org/10.1186/s40623-019-1027-5

Oikawa T, Oba T, Fujinawa A, Sasaki H (2018) Geological study of phreatic eruptions. J Geol Soc Japan 124:231-250. https://doi.org/10.5575/geoso c.2017.0071

Stix J, de Moor JM (2018) Understanding and forecasting phreatic eruptions driven by magmatic degassing. Earth Planets Space 70:83. https://doi. org/10.1186/s40623-018-0855-z

Tanaka R, Hashimoto T, Matsushima N, Ishido T (2018) Contention between supply of hydrothermal fluid and conduit obstruction: inferences from numerical simulations. Earth Planets Space 70:72. https://doi. org/10.1186/s40623-018-0840-6

Tsunematsu K, Chopard B, Falcone J, Bonadonna C (2014) A numerical model of ballistic transport with collisions in a volcanic setting. Comput Geosci 63:62-69. https://doi.org/10.1016/j.cageo.2013.10.016

Ueda H, Nagai M, Tanada T (2018) Phreatic eruptions and deformation of loto Island (Iwo-jima), Japan, triggered by deep magma injection. Earth Planets Space 70:38. https://doi.org/10.1186/s40623-018-0811-y

Walsh B, Procter J, Lokmer l et al (2019) Geophysical examination of the 27 April 2016 Whakaari/White Island, New Zealand, eruption and its implications for vent physiognomies and eruptive dynamics. Earth Planets Space 71:25. https://doi.org/10.1186/s40623-019-1003-0

Yaguchi M, Ohba T, Sago M (2019) The nature and source of the volcanic ash during the 2015 small phreatic eruption at Hakone volcano, central Japan. Geochem J 53:209-217. https://doi.org/10.2343/geochemj.2.0560

Yamaoka K, Geshi N, Hashimoto T et al (2016) Special issue "the phreatic eruption of Mt. Ontake volcano in 2014" the Phreatic Eruption of Mt. Ontake Volcano in 2014 5. Volcanology. Earth Planets Space 68:175. https://doi. org/10.1186/s40623-016-0548-4

Yoshimura R, Ogawa Y, Yukutake Y et al (2018) Resistivity characterisation of Hakone volcano, Central Japan, by three-dimensional magnetotelluric inversion. Earth Planets Space 70:66. https://doi.org/10.1186/s4062 3-018-0848-y 
Yukutake Y, Ito H, Honda R et al (2011) Fluid-induced swarm earthquake sequence revealed by precisely determined hypocenters and focal mechanisms in the 2009 activity at Hakone volcano, Japan. J Geophys Res Solid Earth 116:B04308. https://doi.org/10.1029/2010JB008036

Yukutake Y, Honda R, Harada M et al (2017) Analyzing the continuous volcanic tremors detected during the 2015 phreatic eruption of the Hakone volcano. Earth Planets Space 69:164. https://doi.org/10.1186/s4062 3-017-0751-y
Yukutake Y, Ichihara M, Honda R (2018) Infrasonic wave accompanying a crack opening during the 2015 Hakone eruption. Earth Planets Space 70:53. https://doi.org/10.1186/s40623-018-0820-x

\section{Publisher's Note}

Springer Nature remains neutral with regard to jurisdictional claims in published maps and institutional affiliations.
Submit your manuscript to a SpringerOpen ${ }^{\circ}$ journal and benefit from:

- Convenient online submission

- Rigorous peer review

- Open access: articles freely available online

- High visibility within the field

Retaining the copyright to your article

Submit your next manuscript at $\boldsymbol{\sim}$ springeropen.com 